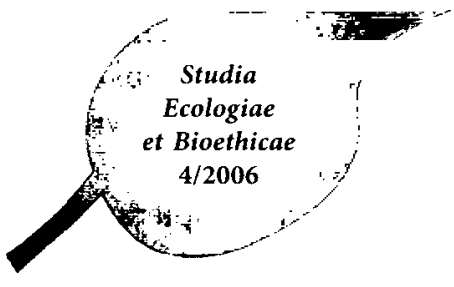

IEiB UKSW Warszawa

\title{
Program "Wspieranie edukacji ekologicznej w placówkach oświatowych m. st. Warszawy"
}

Program powstał w 2002 roku i pierwotnie nosił nazwę: „Program edukacji ekologicznej m. st. Warszawy dla dzieci w wieku przedszkolnym i wczesnoszkolnym”. Obecnie występuje pod nazwą: „Wspieranie edukacji ekologicznej w placówkach oświatowych m. st. Warszawy". Zmiana ta podyktowana została chęcią rozszerzenia obszarów działalności Programu.

Inicjatorkami Programu są: J. Dybysławska, E. Pytlak, H. Waszkiewicz, które to prowadzą instruktaże edukacji ekologicznej Mazowieckiego Regionalnego Ośrodka Edukacji Ekologicznej - Fundacji Ośrodka Edukacji Ekologicznej EKO - OKO.

Niniejszy Program realizowany jest dzięki współpracy Biura Edukacji Miasta Stołecznego Warszawy oraz Biura Ochrony Środowiska z Wydziałami Oświaty i Wychowania warszawskich dzielnic. Wsparcie finansowe zapewnione jest ze środków Miasta.

Program bezpośrednio skierowany został do nauczycieli przedszkoli i nauczania zintegrowanego oraz wszelkich placówek wdrażających edukację ekologiczną wśród dzieci w wieku przedszkolnym i wczesnoszkolnym. Ogólną jego ideą jest propagowanie zachowań pro środowiskowych za pomocą edukacji ekologicznej mając na celu założenia znajdujące się w Agendzie 21 i działania oparte o zasady zrównoważonego rozwoju.

Na Program składa się sześć części dotyczących problematyki związanej z:

- Ochroną powietrza

- Ochroną przed hałasem

- Ochroną wód i racjonalnym ich wykorzystaniem

- Segregacją odpadów

- Ochroną gleby i kształtowaniem zieleni

- Zdrowym stylem życia

Każde z powyższych zagadnień ma wyszczególnione cele, zakres treści oraz prognozy wyników. 
Ponadto Program zawiera pakiet informacyjno - edukacyjny posiadający przykładowe scenariusze zajęć, schematy do realizowanych zadań, a także karty pracy dla uczniów wraz z instrukcjami do przeprowadzania i opisywania doświadczeń.

Program „Wspieranie edukacji ekologicznej w placówkach oświatowych m. st. Warszawy" jest ciekawą propozycją realizacji aspektu formalnego edukacji ekologicznej już od najmlodszych lat. Dzięki temu uczniowie będą mogli wykazać się lepszą znajomością problemów zachodzących w środowisku przyrodniczym, co zaowocuje w przyszłości.

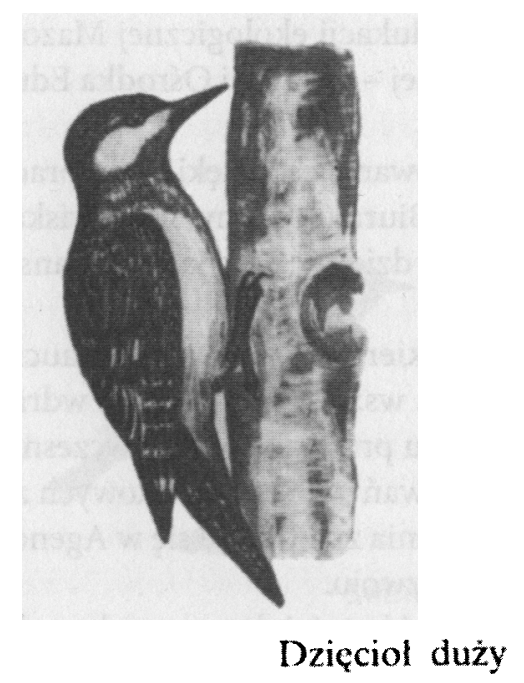

